\title{
Analisis E-Service Quality Terhadap Loyalitas Nasabah dengan Kepuasan Sebagai Variabel Intervening
}

\author{
Desi Astuti, Megasari Gusandra Saragih* \\ Universitas Pembangunan Panca Budi, Medan, Indonesia \\ Email: 1desiastuti1996@gmail.com, 2,*megasarigusandrasaragih@dosen.pancabudi.ac.id \\ Email Penulis Korespondensi: megasarigusandrasaragih@dosen.pancabudi.ac.id \\ Submitted: 21/11/2021; Accepted: 29/11/2021; Published: 30/11/2021
}

\begin{abstract}
Abstrak-Penelitian dilakukan untuk menganalisis pengaruh e-service quality terhadap loyalitas nasabah yang dimediasi oleh kepuasan. Sampel dalam penelitian ini adalah 128 nasabah PT Bank Rakyat Indonesia (BRI) Kantor Cabang Medan jalan Gatot Subroto, Medan. Penelitian ini berjenis penelitian kuantitatif dengan sumber data primer yaitu dengan membagikan kuesioner kepada responden dengan skala likert 1-5. Metode analisis yang digunakan adalah struktur berjenjang dengan Structural Equation Modeling (SEM) dengan menggunakan perangkat AMOS-20 (Analysis of Moment Structure). Hasil penelitian menunjukkan bahwa e-service quality berpengaruh signifikan terhadap kepuasan dan loyalitas nasabah BRI Kantor Cabang Medan. Kepuasan berpengaruh signifikan terhadap loyalitas nasabah BRI Kantor Cabang Medan. Kepuasan memediasi secara partial mediation pengaruh e-service quality terhadap loyalitas nasabah BRI Kantor Cabang Medan.
\end{abstract}

Kata Kunci: E-Service Quality; Loyalitas; Kepuasan.

\begin{abstract}
The study was conducted to analyze the effect of e-service quality on customer loyalty mediated by satisfaction. The sample in this study were 135 customers of PT Bank Rakyat Indonesia (BRI) Medan Branch Office Gatot Subroto Street, Medan. This research is a quantitative research with primary data sources, namely by distributing questionnaires to respondents with a Likert scale of 1-5. The analytical method used is a tiered structure with Structural Equation Modeling (SEM) using the AMOS20 (Analysis of Moment Structure) device. The results showed that e-service quality had a significant effect on customer satisfaction and loyalty at BRI Medan Branch Office. Satisfaction has a significant effect on customer loyalty at BRI Medan Branch Office. Satisfaction partially mediates the effect of e-service quality on customer loyalty at BRI Medan Branch Office.
\end{abstract}

Keywords: E-Service Quality; Loyalty; Satisfaction

\section{PENDAHULUAN}

Perkembangan teknologi informasi yang semakin maju saat ini, membuat nasabah menjadi lebih selektif dalam memilih suatu produk atau jasa perbankan yang diinginkannya. Para bank pun berlomba-lomba bersaing untuk mendapatkan perhatian nasabah, agar nasabah tersebut datang kembali untuk melakukan transaksi perbankan melalui internet. Bukan hanya dengan memberikan jasa yang terbaik, tetapi perbankan juga memberikan kualitas layanan yang terbaik untuk menarik perhatian nasabah. Kualitas layanan secara langsung diukur dari keramahan penjual bertemu langsung dengan pembeli, lain halnya dengan kualitas layanan elektronik. Kualitas layanan elektronik diukur dari kemudahan yang diberikan oleh bank melalui media internet atau website bank. Rowley (2006) layanan elektronik di definisikan sebagai perbuatan, usaha atau pertunjukan yang pengiriman di mediasi oleh teknologi informasi. Layanan elektronik tersebut meliputi unsur layanan e-tailing, dukungan pelanggan, dan pelayanan. Kualitas layanan merupakan hal penting karena akan berdampak langsung pada citra perusahaan. Ketika pelanggan puas terhadap layanan yang diberikan oleh perusahaan, maka hal tersebut akan meningkatkan loyalitas pelanggan terhadap perusahaan.

Menurut Rangkuti (2009) kepuasan pelanggan didefinisikan sebagai respon pelanggan terhadap ketidaksesuaian antara tingkat kepentingan sebelumnya dan kinerja aktual yang dirasakan setelah pemakaian. Kepuasan nasabah terhadap suatu jasa perbankan, sebenarnya sesuatu yang sulit untuk didapat jika bank tersebut tidak benar-benar mengerti apa yang diharapkan oleh konsumen. Untuk produk atau layanan dengan kualitas yang sama, dapat memberikan tingkat kepuasan yang berbeda-beda bagi nasabah yang berbeda. Oleh karena itu, suatu bank harus selalu memperhatikan kualitas produk maupun pelayanan yang diberikan kepada nasabah.

Meningkatnya intensitas persaingan dari pesaing menuntut pihak perbankan untuk melakukan inovasi dalam memberikan pelayanan kepada para pelanggan dan untuk mendapatkan pelanggan baru, dengan cara memaksimalkan pelayanan mereka secara elektronik melalui internet yang dikenal dengan e-service. E-service quality merupakan versi baru dari service quality (ServQual). E-Service Quality dikembangkan berdasarkan kemajuan teknologi informasi yang ada untuk mengevaluasi suatu pelayanan yang diberikan pada jaringan internet.

E-service yang baik akan menimbulkan kepuasan kepada pelanggan. Kepuasan pelanggan merupakan faktor penentuan yang signifikan dari pengulangan pembelian, informasi dari mulut ke mulut yang positif dan kesetiaan/loyalitas pelanggan. Kepuasan pelanggan akan mempengaruhi intensitas perilaku untuk membeli jasa dari penyedia jasa yang sama (Assegaff, 2009). Kepuasan pelanggan memiliki peran mediasi penting antara kualitas layanan dan loyalitas pelanggan (Akbar \& Parvez, 2009).

Senada dengan teori yang diungkapkan oleh Reichheld and Schefter (2000) dijelaskan bahwa dalam rangka menciptakan loyalitas konsumen tentunya merupakan hal penting yang perlu dilakukan oleh pelaku bisnis. Loyalitas akan tercipta dengan kepuasan pelanggan yang merasa bahwa keinginannya sudah terpenuhi. Oleh sebab itulah 
keinginan pelanggan menjadi satu kunci perusahaan untuk tetap eksis, dari sinilah kita dapat membangun dasar dari masukan pelanggan untuk terus berjaya di era globalisasi melalui e-service quality.

PT Bank Rakyat Indonesia Kantor Cabang Medan yang selanjutnya ditulis dengan BRI Kantor Cabang Medan adalah salah satu perbankan milik pemerintah yang saat ini menduduki posisi sebagai salah satu bank terbesar di Indonesia. Banyaknya pesaing yang memiliki kapasitas yang kuat dengan berbagai macam strategi yang mumpuni menjadi tantangan tersendiri bagi BRI untuk terus mempertahankan posisinya sebagai perbankan terbesar di Indonesia. Dalam hal ini, BRI Kantor Cabang Medan memaksimalkan e-service yang dimiliki dengan berbagai macam fasilitas untuk membuat nasabah menjadi mudah dan efisien sebagai dampak dari berkembangnya teknologi serta globalisasi oleh karena itulah peneliti mengasumsikan bahwa ketika nasabah merasakan pengalaman bertransaksi yang baik, maka tingkat loyalitas akan meningkat sama halnya ketika nasabah akan loyal karena ia merasa puas tetapi tanpa merasa puas pun nasabah juga akan tetap loyal terhadap bank, karena e-service quality yang diberikan BRI Kantor Cabang Medan saat ini cukup efektif serta efisien terutama untuk mengatasi permasalahan antrian yang cukup panjang apabila nasabah bertransaksi langsung ke bank dan juga Anjungan Tunai Mandiri (ATM) dari BRI yang sering bermasalah dan hal ini selalu dikeluhkan oleh nasabah BRI.

Loyalitas nasabah menjadi hal yang paling penting guna mempertahankan nasabah. E-service quality yang baik akan mendukung BRI Kantor Cabang Medan dalam memberikan pelayanan yang lebih baik lagi sehingga menciptakan kepuasan pada nasabah yang selanjutnya akan berpengaruh pada loyalitas terhadap BRI Kantor Cabang Medan untuk meningkatkan jumlah transaksi dan menarik nasabah baru, maka diperlukan analisis $e$-service quality terhadap tingkat kepuasan dan juga loyalitas pelanggan.

\section{METODE PENELITIAN}

\subsection{Pendekatan Penelitian}

Penelitian ini merupakan jenis penelitian kuantitatif dengan pendekatan asosiatif. Metode penelitian kuantitatif asosiatif merupakan penelitian yang bertujuan untuk mengetahui pengaruh ataupun hubungan antara dua variabel atau lebih. Objek dalam penelitian ini adalah seluruh nasabah dari BRI Kantor Cabang Medan yang beralamat di jalan Gatot Subroto, Medan.

\subsection{Operasional Variabel}

Loyalitas konsumen merupakan suatu komitmen untuk membeli kembali suatu barang atau jasa secara konsisten di masa yang akan datang. Oliver (1997) menyatakan bahwa loyalitas adalah suatu kesediaan pelanggan untuk melanjutkan pembelian pada sebuah perusahaan dalam jangka waktu yang panjang dan mempergunakan produk atau pelayanan secara berulang, serta merekomendasikannya kepada teman-teman dan perusahaan lain secara sukarela. Adapun indikator pengukuran variabel loyalitas pelanggan menurut Griffin (2005) adalah sebagai berikut : (1) Melakukan pembelian berulang (2) Menunjukkan kekebalan daya tarik produk sejenis dari perusahaan pesaing (3) Merekomendasikan kepada orang lain. Selanjutnya dalam penelitian ini loyalitas nasabah akan diberikan symbol Y.

Voss (2003) mendefinisikan layanan dalam lingkungan elektronik (e-service) sebagai "the delivery as service using new media such as the web". Definisi tersebut berarti penyerahan jasa dengan menggunakan media yang baru yaitu web. Keberadaan bukti dari kualitas layanan atas penyerahan melalui website merupakan kesuksesan strategi yang sangat penting di bandingkan dengan harga murah dan keberadaan web (Zeithaml dkk., 2002). Adapun indikator pengukuran dalam variabel ini adalah sebagai berikut : (1) Ease of Use; (2) Website Design; (3) Reliability; (4) System Availability; (5) Privacy; (6) Responsiveness; (7) Empathy; (8) Experience; (9) Trust. Selanjutnya dalam penelitian ini $e$-service quality akan diberikan symbol X.

Kepuasan pelanggan adalah perasaan senang atau kecewa seseorang yang muncul setelah membandingkan antara harapan terhadap kenyataan yang diperoleh menurut Kotler (2009). Indikator-indikator dalam kepuasan pelanggan adalah: (1) Membeli/mengirim kembali, (2) Menciptakan word of mouth yaitu mengatakan hal-hal yang baik tentang perusahaan kepada orang lain, (3) Menciptakan citra merek, dan (4) Perilaku komplain yaitu pelanggan yang puas cenderung lebih kecil kemungkinannya melakukan komplain. Selanjutnya dalam penelitian ini kepuasan akan diberikan symbol Z.

\subsection{Populasi dan Sampel}

Untuk penentuan jumlah sampel dalam penelitian ini juga mempertimbangkan model penelitian yang digunakan. Model penelitian yang digunakan dalam penelitian ini adalah model Structural Equation Modelling (SEM), dimana dalam SEM jumlah sampel yang ideal antara 100-200 (Hair et al, 2009) dan juga harus mempertimbangkan jumlah indikator yang ada dalam model. Hair et al (2009) lebih lanjut mengatakan untuk penentuan jumlah sampel dapat berjumlah 5-10 dari jumlah indikator. Jumlah sampel ditentukan dengan mengalikan jumlah indikator dengan 10, sehingga total sampel sebanyak 16 x $8=128$ responden. Dimana teknik pengambilan sampel dilakukan dengan menggunakan teknik nonprobability sampling dengan pendekatan purposive sampling. Dimana hanya nasabah yang sudah menjadi nasabah di BRI Kantor Cabang Medan minimal selama 2 tahun yang dapat dijadikan sebagai responden. 


\subsection{Teknik Analisis Data}

Subsequent full models in this study can be described as follows:

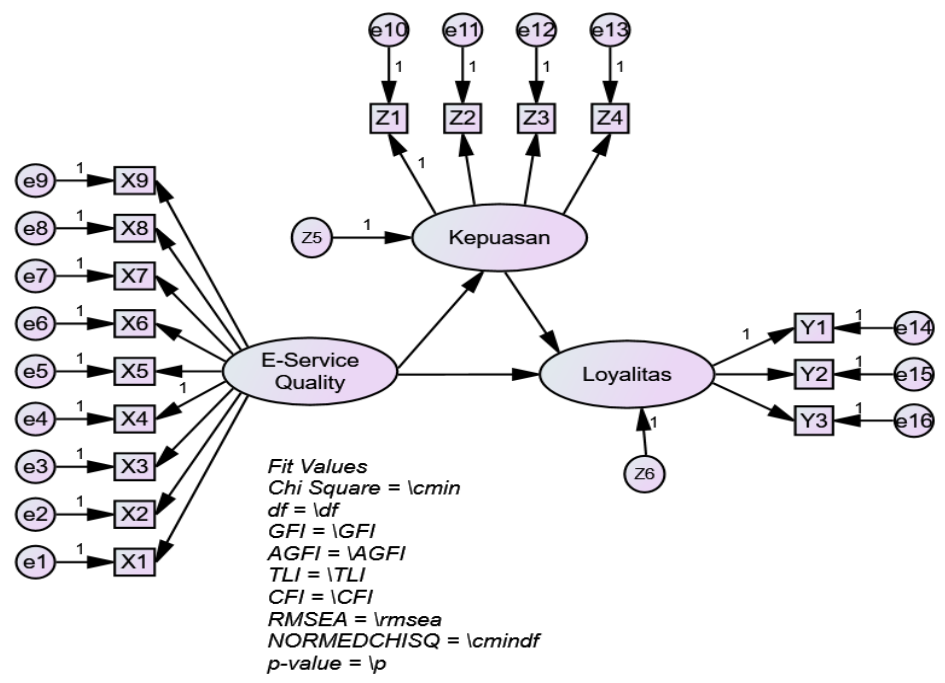

Gambar 1. Full Model Penelitian

The equation in this study can be formulated as follows:

\begin{tabular}{|c|c|c|}
\hline $\mathrm{Z}$ & $=$ & $b_{1} \mathrm{X}+\mathrm{Z}_{5} \ldots \ldots \ldots \ldots \ldots \ldots \ldots \ldots \ldots \ldots \ldots \ldots \ldots$ \\
\hline Y & $=$ & $b_{1} \mathrm{X}+b_{2} \mathrm{Z}+\mathrm{Z}_{6} \ldots \ldots \ldots \ldots \ldots$ \\
\hline \multicolumn{3}{|c|}{ Dimana: } \\
\hline $\mathrm{X}$ & $=$ & E-service Quality \\
\hline $\mathrm{Y}$ & $=$ & Loyalitas Nasabah \\
\hline $\mathrm{Z}$ & $=$ & Kepuasan \\
\hline b1-b2 & $=$ & Koefisien Estimasi \\
\hline $\mathrm{Z}_{6}-\mathrm{Z}_{7}$ & $=$ & error term (nilai residual) \\
\hline
\end{tabular}

Uji statistik dilakukan dengan mengamati tingkat signifikansi hubungan antar variabel yang ditunjukkan oleh nilai C.R (Critical Ratio) yang identik dengan uji-t pada regresi dan nilai probabilitas (P). Hubungan yang signifikan ditandai dengan nilai C.R lebih besar dari 2,58 dan nilai P lebih kecil dari 0,05 (Ferdinand, 2014). Selanjutnya untuk melihat pengaruh variabel moderasi menggunakan teori Sobel Test dari Baron dan Kenny (1986).

\section{HASIL DAN PEMBAHASAN}

\subsection{Hasil Penelitian}

\subsubsection{Karakteristik Responden}

Berdasarkan hasil analisis dari karakteristik responden pada penelitian ini dapat dibuat kesimpulan secara umum bahwa nasabah BRI Kantor Cabang Medang didominasi oleh nasabah perempuan, usia berkisar antara 30 - 39 tahun, sudah menikah dengan jenis pekerjaan mayoritas sebagai pegawai swasta.

\subsubsection{Deskripsi Jawaban Responden}

Nilai rata-rata (mean) jawaban responden tentang variabel e-service quality sebesar 3,789 atau dibulatkan menjadi 4 atau pada kondisi setuju. Nilai standar deviasi sebesar 0,744 menunjukkan bahwa sebaran data sudah baik karena nilai tersebut tidak melebihi tiga kali nilai mean. Hal ini berarti secara umum e-service quality di BRI Kantor Cabang Medang sudah baik namun masih perlu ditingkatkan lagi agar dapat berada di skala 5. Ini dikarenakan dari salah satu indikator e-service quality yaitu ease of use (kemudahan dalam penggunaan) dinilai masih kurang oleh nasabah, karena masih seringnya terjadi error atau gangguan jaringan secara tiba-tiba yang menyebabkan terkendalanya transaksi keuangan nasabah.

Nilai rata-rata mean jawaban responden tentang variabel kepuasan sebesar 3,735 atau dibulatkan menjadi 4 atau pada kondisi setuju, hal ini berarti secara umum responden berpendapat bahwa nasabah BRI Kantor Cabang Medan sudah merasa puas terhadap pelayanan elektronik yang diberikan oleh BRI. Nilai standar deviasi sebesar 0,7886 menunjukkan bahwa sebaran data sudah baik karena nilai tersebut tidak melebihi tiga kali nilai mean. Tingkat kepuasan nasabah di BRI Kantor Cabang Medang sudah baik namun masih perlu ditingkatkan lagi agar dapat berada di skala 5. Karena berdasarkan hasil analisis dari jawaban responden masih ditemukannya nasabah 
yang melakukan komplain terhadap pelayanan elektronik dari BRI. Komplain ini tentu saja menunjukkan bahwa masih terdapat nasabah yang tidak puas terhadap pelayanan elektronik yang diberikan oleh BRI.

Nilai rata-rata (mean) jawaban responden tentang variabel loyalitas nasabah sebesar 3,810. Apabila dihubungkan dengan skala yang ditentukan dalam penelitian ini maka kategori jawaban responden secara rata-rata berada pada skala (4) atau pada kondisi setuju, dengan nilai standar deviasi sebesar 0,745 menunjukkan bahwa sebaran data sudah baik, karena nilai tersebut tidak melebihi tiga kali nilai mean. Dapat disimpulkan bahwa loyalitas nasabah pada BRI Kantor Cabang Medan sudah tinggi, namun masih perlu ditingkatkan lagi. Karena masih ditemukan banyaknya nasabah yang juga menjadi nasabah dari bank lain dikarenakan tidak semua aktivitas perbankan mereka dapat terpenuhi hanya dengan menggunakan transaksi melalui BRI sehingga mereka masih menggunakan bank lain untuk menutupi kekurangan tersebut. Ini mengindikasikan bahwa loyalitas dari BRI Kantor Cabang Medan masih belum optimal.

\subsubsection{Uji Normalitas Data}

Hasil uji normalitas data dapat dilihat dari Tabel berikut ini:

Tabel 1. Uji Normalitas Data

Assessment of normality (Group number 1)

\begin{tabular}{ccccccc}
\hline Variable & $\min$ & $\max$ & skew & c.r. & kurtosis & c.r. \\
\hline X1 & 2,000 & 5,000 &, 025 &, 119 &,- 360 &,- 870 \\
X2 & 2,000 & 5,000 &, 132 &, 637 &,- 429 & $-1,036$ \\
X3 & 2,000 & 5,000 &, 037 &, 179 &,- 564 & $-1,361$ \\
Z4 & 2,000 & 5,000 &,- 149 &,- 719 &,- 352 &,- 851 \\
Z3 & 2,000 & 5,000 &, 245 & 1,183 &,- 388 &,- 937 \\
Z2 & 2,000 & 5,000 &, 506 & 2,445 &,- 148 &,- 359 \\
Z1 & 2,000 & 5,000 &,- 016 &,- 079 &,- 604 & $-1,460$ \\
Y3 & 2,000 & 5,000 &, 111 &, 535 &,- 496 & $-1,197$ \\
Y2 & 2,000 & 5,000 &, 095 &, 459 &,- 478 & $-1,155$ \\
Y1 & 2,000 & 5,000 &, 230 & 1,111 &,- 537 & $-1,298$ \\
X9 & 2,000 & 5,000 &, 303 & 1,465 &,- 336 &,- 812 \\
X8 & 2,000 & 5,000 &, 328 & 1,584 &,- 408 &,- 986 \\
X7 & 2,000 & 5,000 &, 091 &, 441 &,- 526 & $-1,270$ \\
X6 & 2,000 & 5,000 &, 128 &, 618 &,- 475 & $-1,147$ \\
X5 & 2,000 & 5,000 &,- 008 &,- 039 &,- 563 & $-1,360$ \\
X4 & 2,000 & 5,000 &, 269 & 1,297 &,- 476 & $-1,149$ \\
\hline Multivariate & & & & & $-6,293$ & $-1,551$ \\
\hline
\end{tabular}

Dari Tabel 1 di atas dapat diketahui bahwa seluruh data dalam penelitian ini terdistribusi normal terlihat dari nilai c.r (curtosis ratio) baik secara univariate dan multivariate yang berada diantara $\pm 2,58$. Dan nilai cr secara multivariate yaitu sebesar -1,551 yang menandakan bahwa data terdistribusi normal dan layak diuji dalam tahap selanjutnya.

\subsubsection{Uji Kesesuaian Model}

Uji kesesuaian model dilakukan melalui diagram alur dalam persamaan full model, yaitu uji yang dilakukan terhadap keseluruhan variabel baik eksogen maupun endogen yang telah digabungkan menjadi satu diagram (path) yang utuh melalui matrik varian atau kovarian dan model penuh itu disebut sebagai model penelitian. Uji full model SEM bertujuan untuk melihat sejauh mana model dasar yang dibentuk dalam penelitian ini memenuhi kriteria goodness of fit sehingga model dapat menggambarkan fenomena penelitian tanpa adanya modifikasi.

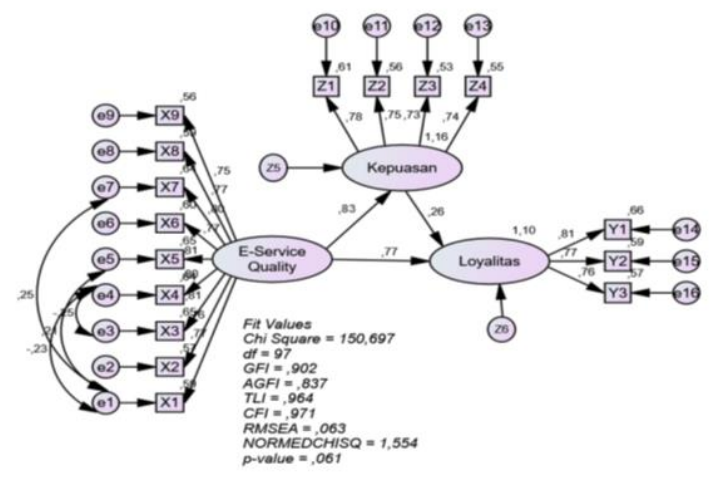

Gambar 2. Full Model Penelitian Setelah Dimodifikasi 
Hasil pengolahan data seperti yang diperlihatkan dalam Gambar 2 kemudian dimasukkan dalam Tabel 1 menunjukkan bahwa keseluruhan semua konstruk yang digunakan untuk membentuk model penelitian ini sudah memenuhi kriteria goodness of fit indeks yang telah ditetapkan seperti nilai chi-square, RMSEA, nilai GFI, TLI, CFI, dan CMIN/DF, kecuali nilai AGFI yang masih marginal $(0,837<0,900)$ tapi sudah mendekati baik. Signifikansi model dilihat dari nilai p-value yang sudah signifikan yaitu sebesar 0,061 yang lebih besar dari 0,05 . Nilai GOF secara keseluruhan dapat dilihat seperti ditunjukkan dalam Tabel 2.

Tabel 1. Kriteria Goodness of Fit Full Model

\begin{tabular}{cccc}
\hline Goodness Of Fit Index & Expected value & Result value & Conclusion \\
\hline$\chi^{2}$ C-square Statistics & Expected small & 150,697 & Good \\
GFI & $\geq 0,90$ & 0,902 & Good \\
AGFI & $\geq 0,90$ & 0,837 & Marginal \\
TLI & $\geq 0,95$ & 0,964 & Good \\
CFI & $\geq 0,95$ & 0,971 & Good \\
RMSEA & $\leq 0,08$ & 0,063 & Good \\
CMIN/DF & $\leq 2,00$ & 1,554 & Good \\
P-Value & $\geq 0,05$ & 0,061 & Good \\
\hline
\end{tabular}

\subsection{Pembahasan}

Untuk melihat seberapa besar pengaruh variabel e-service quality dan kepuasan terhadap loyalitas nasabah dapat ditunjukkan pada Tabel 3 berikut ini.:

Tabel 3. Pengaruh Variabel Dependen Terhadap Variabel Independen

\begin{tabular}{lccrrrrr}
\hline & Latent Variable & Estimate & Std. Estimate & \multicolumn{1}{c}{ S.E. } & C.R. & P \\
\hline Kepuasan & $<---$ & EServiceQuality &, 831 &, 842 &, 092 & 11,761 & $* * *$ \\
Loyalitas & $<---$ & EServiceQuality &, 770 &, 797 &, 105 & 7,606 & $* * *$ \\
Loyalitas & $<---$ & Kepuasan &, 262 &, 269 &, 081 & 3,308 & $* * *$ \\
\hline
\end{tabular}
berikut :

Berdasarkan hasil analisis data seperti yang ditampilkan dalam Tabel 2, maka persamaan struktural sebagai

$$
\begin{aligned}
& \text { Persamaan Struktural I : } \quad \mathbf{Z}=\boldsymbol{b}_{\mathbf{1}} \mathbf{X}+\mathbf{Z}_{\mathbf{5}} \\
& \begin{array}{lll} 
& \mathbf{Z}=\mathbf{0 , 8 3 1} \mathbf{X} \\
\text { Persamaan Struktural II : } & \mathbf{Y}=\boldsymbol{b}_{1} \mathbf{X}+\boldsymbol{b}_{\mathbf{2}} \mathbf{Y}+\mathbf{Z}_{\mathbf{6}}
\end{array} \\
& Y=0,770 X+0,262 Z
\end{aligned}
$$

Berdasarkan Tabel 2, maka dapat peneliti uraikan kesimpulan untuk menjawab hipotesis yang ada dalam penelitian ini, yaitu sebagai berikut:

\section{E-Service Quality Berpengaruh Positif dan Signifikan Terhadap Kepuasan Nasabah BRI Kantor Cabang Medan}

Pengaruh e-service quality terhadap kepuasan nasabah BRI Kantor Cabang Medan adalah positif dan signifikan dengan nilai koefesien estimate standardized regression weight sebesar $0,831(83,1 \%)$, nilai probabilitas atau signifikansi sebesar 0,0001 (signifikan) dan nilai C.R sebesar 11,761 (terima H1). Dengan kata lain bahwa $e$-service quality berpengaruh positif dan signifikan terhadap kepuasan nasabah BRI Kantor Cabang Medan.

Hasil ini didukung oleh penelitian terdahulu yang dikerjakan oleh Lumempow, Mandey, \& Rotinsulu (2015) yang menyebutkan bahwa kualitas pelayanan berpengaruh terhadap kepuasan nasabah. Studi kasus yang dilakukan pada industri online shopping seperti yang dilakukan oleh Kusdibyo \& Februadi (2017) menyebutkan $e$-service quality mempunyai kontribusi signifikan terhadap kepuasan pelanggan. Penelitian yang dilakukan oleh Sundaram, Ramkumar, \& Shankar (2017) juga menyebutkan adanya kontribusi yang signifikan dari e-service quality terhadap kepuasan pelanggan.

\section{E-Service Quality Berpengaruh Positif dan Signifikan Terhadap Loyalitas Nasabah BRI Kantor Cabang Medan}

Pengaruh e-service quality terhadap loyalitas nasabah BRI Kantor Cabang Medan adalah positif dan signifikan dengan nilai koefesien estimate standardized regression weight sebesar 0,770 (77\%), nilai probabilitas atau signifikansi sebesar 0,0001 (signifikan) dan nilai C.R sebesar 7,606 (terima H2). Dengan kata lain bahwa $e$-service quality berpengaruh positif dan signifikan terhadap loyalitas nasabah BRI Kantor Cabang Medan.

Penelitian yang dilakukan oleh Sundaram, Rankumar, \& Shankar (2017) menyebutkan bahwa e-service quality mempunyai kontribusi signifikan terhadap loyalitas pelanggan. Penelitian ini juga didukung oleh penelitian yang dilakukan oleh Rita, Oliveira, \& Farisa (2019) menyatakan pentingnya e-service quality atas loyalitas pelanggan. Hasil yang dipaparkan oleh Sundaram, Rankumar, \& Shankar (2017) dapat membantu menjelaskan pengaruh e-service quality atas loyalitas pelanggan, namun penelitian Sundaram, Rankumar, \& Shankar (2017) tidak spesifik pada perusahaan tertentu dan tidak membedakan pelaku usaha $e$-commerce dengan perusahaan. Hasil pada 
penelitian ini digolongkan juga sebagai competitive atau partial mediation dimana adanya pengaruh yang signifikan $e$-service quality baik secara langsung terhadap loyalitas pelanggan maupun secara tidak langsung melalui kepuasan pelanggan. Selain itu, hubungan antar variabel juga bermakna positif. Artinya, e-service quality yang semakin baik mampu memuaskan pelanggan dan pelanggan yang puas mampu memprediksikan tingkat loyalitasnya.

\section{Kepuasan Berpengaruh Positif dan Signifikan Terhadap Loyalitas Nasabah BRI Kantor Cabang Medan}

Pengaruh kepuasan terhadap loyalitas nasabah BRI Kantor Cabang Medan adalah positif dan signifikan dengan nilai koefesien estimate standardized regression weight sebesar 0,262 (26,2\%), nilai probabilitas atau signifikansi sebesar 0,0001 (signifikan) dan nilai C.R sebesar 3,308 (terima H3). Dengan kata lain bahwa kepuasan berpengaruh positif dan signifikan terhadap loyalitas nasabah BRI Kantor Cabang Medan.

Hasil penelitian ini juga didukung oleh hasil penelitian yang dilakukan oleh Kusdibyo \& Februadi (2019) menyebutkan kepuasan pelanggan berpengaruh terhadap loyalitas pelanggan. Al-dweeri, et. al (2017) menyebutkan kepuasan berpengaruh terhadap loyalitas pelanggan. Rita, Oliveira, \& Farisa (2019) menyatakan kepuasan pelanggan mampu memprediksikan loyalitas pelanggan. Ketiga penelitian tersebut, sama-sama mempunyai obyek penelitian terhadap online shopping sehingga dapat memberikan gambaran mengenai pentingnya kepuasan pelanggan pada loyalitas pelanggan. Selain itu, penelitian yang dilakukan oleh Al-dweeri, et. al (2017) juga membuat variabel kepuasan pelanggan menjadi variabel moderasi, sedangkan penelitian ini adalah intervening dan penelitian ini juga tidak memisahkan pengukuran terhadap loyalitas pelanggan sebagaimana yang ditemukan sama Al-dweeri, et. al (2017).

\section{Kepuasan memediasi pengaruh E-Service Quality terhadap Loyalitas Nasabah BRI Kantor Cabang Medan}

Hasil pengujian efek mediasi (intervening) hubungan variabel e-service quality (variabel prediktor) terhadap loyalitas nasabah (variabel outcome) yang dimediasi oleh kepuasan (variabel mediasi) diringkas dan ditampilkan dalam bentuk gambar seperti Gambar 3, perhitungan nilai signifikansi jalur -c' dilakukan dengan menggunakan software Sobel dapat dilihat pada Gambar 4. Berikut hasil perhitungan nilai signifikansi dengan menggunakan software Sobel:

Details can be found in Baron and Kenny (1986), Sobel (1982), Goodman (1960), and MacKinnon, Warsi, and Dwyer (1995). Insert the $a, b, s_{\mathrm{a}}$ and $s_{\mathrm{b}}$ into the cells below and this program will calculate the critical ratio as a test of whether the indirect effect of the IV on the DV via the mediator is significantly different from zero.

\begin{tabular}{|c|c|c|c|c|c|}
\hline & Input: & & Test statistic: & Std. Error: & $p$-value: \\
\hline a & 0.831 & Sobel test: & 3.01222083 & 0.07227956 & 0.00259344 \\
\hline$b$ & 0.262 & Aroian test: & 2.99594667 & 0.07267219 & 0.00273594 \\
\hline$s_{a}$ & 0.092 & Goodman test: & 3.02876311 & 0.07188479 & 0.00245557 \\
\hline & 0.082 & Reset all & \multicolumn{3}{|c|}{ Calculate } \\
\hline
\end{tabular}

Gambar 3. Mediasi Kepuasan antara E-Service Quality Terhadap Loyalitas Nasabah

Berdasarkan hasil perhitungan seperti pada Gambar 4 ditemukan koefesien jalur $-a$ dan jalur $-b$ signifikan, jalur $-c$ signifikan dan jalur $-c$ ' signifikan. Dengan kata lain variabel kepuasan memediasi secara partial mediation pengaruh antara e-service quality terhadap loyalitas nasabah BRI Kantor Cabang Medan (terima H4), yang bermakna bahwa kepuasan dapat secara langsung berpengaruh terhadap loyalitas nasabah dan juga $e$-service quality dapat berpengaruh terhadap loyalitas nasabah melalui kepuasan. Pelanggan yang puas akan memberikan opini bahwa pelayanan yang diberikan oleh bank sudah berkualitas dan puas. Kepuasan adalah suatu tahap dalam sikap yang menentukan loyalitas nasabah.

\section{KESIMPULAN}

Berdasarkan hasil analisis yang telah dilakukan, maka hasil penelitian ini dapat disimpulkan bahwa pengaruh $e$ service quality terhadap kepuasan nasabah BRI Kantor Cabang Medan adalah positif dan signifikan dengan nilai koefesien estimate standardized regression weight sebesar $0,831(83,1 \%)$, nilai probabilitas atau signifikansi sebesar 0,0001 (signifikan) dan nilai C.R sebesar 11,761. Dengan kata lain bahwa e-service quality berpengaruh positif dan signifikan terhadap kepuasan nasabah BRI Kantor Cabang Medan. Pengaruh e-service quality terhadap loyalitas nasabah BRI Kantor Cabang Medan adalah positif dan signifikan dengan nilai koefesien estimate standardized regression weight sebesar 0,770 (77\%), nilai probabilitas atau signifikansi sebesar 0,0001 (signifikan) dan nilai C.R sebesar 7,606. Dengan kata lain bahwa e-service quality berpengaruh positif dan signifikan terhadap loyalitas nasabah BRI Kantor Cabang Medan. Pengaruh kepuasan terhadap loyalitas nasabah BRI Kantor Cabang Medan adalah positif dan signifikan dengan nilai koefesien estimate standardized regression weight sebesar 0,262 (26,2\%), 
nilai probabilitas atau signifikansi sebesar 0,0001 (signifikan) dan nilai C.R sebesar 3,308. Dengan kata lain bahwa kepuasan berpengaruh positif dan signifikan terhadap loyalitas nasabah BRI Kantor Cabang Medan. Dengan kata lain variabel kepuasan memediasi secara partial mediation pengaruh antara e-service quality terhadap loyalitas nasabah BRI Kantor Cabang Medan, yang bermakna bahwa kepuasan dapat secara langsung berpengaruh terhadap loyalitas nasabah dan juga $e$-service quality dapat berpengaruh terhadap loyalitas nasabah melalui kepuasan.

\section{UCAPAN TERIMAKASIH}

Terima kasih peneliti ucapkan kepada para responden yang sudah banyak membantu peneliti dalam mengisi kuesioner yang diberikan dan terkhusus ucapan terima kasih juga peneliti sampaikan kepada BRI Kantor Cabang Medan dan seluruh pihak yang telah membantu peneliti sehingga penelitian ini dapat terselesaikan dengan baik.

\section{REFERENCES}

Akbar M.M and Parvez. 2009. Impact of Service Quality, Trust, and Customer Satisfaction Loyalty, ABAC Journal, Vol. 29, No.1. Januari, 24-38.

Al-dweeri, Obeidat, Al-dwiry, Alshurideh, \& Alhorani. (2017). The Impact of E-Service Quality and E-Loyalty on Online Shopping: Moderating Effect of E-Satisfaction and E-Trust. International Journal of Marketing Studies, 92-103.

Assegaff, Mohammad. 2009. Pengaruh Kualitas Pelayanan Terhadap Kepuasan Pelanggan Studi Pada Perusahaan Penerbangan PT. Garuda Di Kota Semarang. Jurnal Ekonomi dan Bisnis. Vol. 10. No. 2. Juli. Unisulla Semarang. Semarang.

Baron, Reuben M., dan Kenny, David A, 1986, The Moderator-Mediator Variable Distinction in Social Psychological Research: Conceptual, Strategic, and Statistical Considerations, Journal of Personality and Social Psychology, Volume 51.

Davidson, Carl and Philip Voss. 2003. Knowledge Management, An Indroduction to Creating Advantage from Intelectal Capital.Vision Book. New Delhi.

Ferdinand, Augusty. (2014). Metode Penelitian Manajemen, Undip Press ISBN: 9799-704-254.

Hair, J. F. JR., et al. (2009). Multivariate Data Analysis. Seventh Edition. Uper Sadle River. New Jersey: PrenticeHall.

Kotler dan Keller. 2009. Manajemen Pemasaran. Jilid I. Edisi ke 13 Jakarta: Erlangga.

Kusdibyo. (2019). The Effect of Electronic Service Quality on Customers Satisfaction and Loyalty in Online Shopping. IOP Conference Series: Materials Science and Engineering (pp. 1-8). Bandung: INCITEST.

Lumempow, N. R., Mandey, S., \& Rotinsulu, J. J. (2015). Analisis Faktor-Faktor Kualitas Pelayanan Terhadap Kepuasan Nasabah Pada Pt. Bank Mandiri Tbk Cabang Bahu Mall Manado. Jurnal EMBA.

Oliver, Riscrd L, 1997, Satisfaction A Behavioral Perspective On The. Consumer. McGraw-Hill Education, Singapore.

Rangkuti, Freddy 2002,Measuring Customer Satisfaction, Penerbit PT. Gramedia Pustaka Utama, Jakarta.

Reichheld, F.F., Schefter, P. 2000. E-Loyalty. Harvard Business Review, Vol.78 No. 4.

Rita, Oliveira, \& Farissa. (2019). The impact of e-service quality and customer satisfaction on customer behavior in online shopping. Heliyon , 5, 1-14.

Rowley, J. (2006). An analysis of the e-service literature: towards a research agenda. Internet Research, 16(3), 339-359.

Sundaram, Ramkumar, \& Shankar. (2017). Impact of E-Service Quality on Customer Satisfaction and Loyalty Empirical Study in India Online Business. KINERJA, 21 (1), 48-69.

Zeithaml, et al. 2002. Service Quality Delivery Through Web Sites: A Critical Review of Extant Knowledge. Journal of the academy of marketing science. 